\begin{tabular}{|c|l|}
\hline Title & Restriction fragment length polymorphism of nuclear rDNA in Sorex caecutiens/shinto group (Eulipotyphla, Soricidae) \\
\hline Author(s) & Naitoh, Y ukako; Iwasa, Masahiro A .; Ohdachi, Satoshi D.; Han, Sang-Hoon; Suzuki, Hitoshi \\
\hline Citation & $\begin{array}{l}\text { Mammal Study, 30(2), 101-107 } \\
\text { https://doi.org/10.3106/1348-6160(2005)30[101:RFLPON]2.0.C0;2 }\end{array}$ \\
\hline Issue Date & 2005 \\
\hline Doc URL & http://hdl.handle.net/2115/44410 \\
\hline Type & article \\
\hline File Information & MS30-2_101-107.pdf \\
\hline
\end{tabular}

Instructions for use 


\title{
Restriction fragment length polymorphism of nuclear rDNA in Sorex caecutiens/shinto group (Eulipotyphla, Soricidae)
}

\author{
Yukako Naitoh ${ }^{1}$, Masahiro A. Iwasa ${ }^{2}$, Satoshi D. Ohdachi1,", Sang-Hoon Han ${ }^{3}$ \\ and Hitoshi Suzuki ${ }^{4}$
}

${ }^{\prime}$ Institute of Low Temperature Science, Hokkaido University, Sapporo 060-0819, Japan

${ }^{2}$ Laboratory of Wildlife Science, Department of Animal Science and Resources, College of Bioresource Sciences, Nihon University, Kameino 1866, Fujisawa, Kanagawa 252-8510, Japan

${ }^{3}$ Asiatic Black Bear Management Team, National Parks Authority, 511-1 Whangjeon-ri, Masan-myeon, Gurye-gun, Jeolla-Namdo 542-853, Republic of Korea

${ }^{4}$ Laboratory of Ecology and Genetics, Graduate School of Environmental Earth Science, Hokkaido University, Sapporo 060-0810, Japan

\begin{abstract}
We estimated phylogenetic relationships among shrews of the Sorex caecutiens/shinto group (Eulipotyphla, Soricidae) from various locations through its range, based on restriction fragment length polymorphism (RFLP) analysis of the nuclear ribosomal RNA gene (rDNA) spacer region. Seven rDNA-RFLP repetitive types (repetypes) were recognized among 15 shrews examined. Restriction patterns of Sorex caecutiens Laxmann, 1788 and S. shinto Thomas, 1905 were distinguishable from each other, but the separation was not statistically supported in the maximum parsimony analysis. The RFLP repetype from Cheju Island was close to that of $S$. caecutiens from the Eurasian continent, indicating that the shrew of Cheju should be classified as $S$. caecutiens. Within $S$. caecutiens, there were two alternative phylogenetic hypotheses. According to a parsimonious tree and a simple network, the Hokkaido population was regarded to be derived from the Sakhalin population, which in turn was derived from the continental population. Alternatively, it was inferred that the continent and Hokkaido populations were firstly separated from the ancestral population, and then shrews from both populations immigrated into Sakhalin and hybridization occurred there. The latter hypothesis seems to be more plausible because it is more congruent with a previous mitochondrial phylogeny.
\end{abstract}

Key words: Cheju Island, nuclear rDNA, RFLP, Sorex caecutiens.

Taxonomic ranks of Sorex caecutiens Laxmann, 1788 and S. shinto Thomas, 1905 had been debated by various authors because interpretation of their morphology is difficult (see Dokuchaev et al. 1999) and little phylogenetic information was available for these shrews. However, after phylogenetic investigations of some species of Sorex (George 1988; Ohdachi et al. 1997; Fumagalli et al. 1999), it is now widely accepted that these two species are distinct. Further, Ohdachi et al. (1997, 2001, 2003) revealed based on mitochondrial cytochrome $b$ gene (mtDNA cyt- $b$ ) sequences that $S$. caecutiens and $S$. shinto form a monophyletic group $(S$. caecutiens/shinto group), and that $S$. caecutiens occurs in the Eurasian continent, Sakhalin, Hokkaido, and neighboring small islands while $S$. shinto is distributed in the southern parts of the Japanese Islands (Honshu, Shikoku, and Sado). From Cheju Island, South Korea, a Sorex shrew species was recently discovered $(\mathrm{H}$. S. Oh, personal observation). It has not yet been formally described but initial observation suggests it belongs to the $S$. caecutiens/ shinto group. Ohdachi et al. (2003) showed that the shrew on Cheju Island should be included in $S$. caecutiens, based on mtDNA cyt- $b$ sequences.

According to the phylogenetic tree based on mtDNA cyt- $b$, there are two main clusters in $S$. caecutiens: the Hokkaido cluster and the Eurasian Continent-Sakhalin-

*To whom correspondence should be addressed. E-mail: ohd@pop.lowtem.hokudai.ac.jp 
Cheju cluster (Ohdachi et al. 2003; Ohdachi 2005). Furthermore, it was demonstrated that genetic variation was low and there was almost no local divergence of haplotype among individuals of $S$. caecutiens from the Eurasian continent and Sakhalin (Ohdachi et al. 2001, 2003). Based on these results, Ohdachi et al. (2001, 2003) suggested that the ancestral population of $S$. caecutiens were first divided into two subpopulations, one in Hokkaido and the other in the eastern part of the Eurasian continent. Then, the latter subpopulation spread rapidly throughout the continent and Sakhalin after the last glacial period.

Phylogenetic trees inferred from mtDNA, however, sometimes contradict those inferred from nuclear DNA (e.g. Mukai 2001; Sota and Vogler 2001; Iwasa and Suzuki 2002). In such cases, taxonomy and evolutionary events inferred from mtDNA alone will lead to erroneous conclusions. In the $S$. caecutiens/shinto group, phylogenetic investigations based on nuclear DNA have not been conducted. Thus, it is needed to infer the phylogeny from the information of nuclear DNA.

In the present paper, we investigate restriction fragment length polymorphism (RFLP) of nuclear ribosomal RNA genes (rDNA) and estimate the phylogenetic relationships between species or populations in the $S$. caecutiens/shinto group. In addition, phylogenetic status of the Sorex shrew from Cheju Island is investigated. Herein, we shortly summarize the nature of nuclear
rDNA. The rDNA gene unit multiplies several hundred times in a nuclear genome and forms a multigene family. Thus, it is useful to estimate an overall genetic variation of a nuclear genome of an individual in a population. The rDNA gene unit is composed of the coding and spacer regions. The former regions, which encode highly conserved rDNA (18S, 5.8S, and 28S), are suitable as probe-anchoring regions (Arheim et al. 1980). The spacer regions, in contrast, are known to evolve rapidly and are useful to detect variation between and within species in phylogenetic inferences (e.g. Arheim et al. 1980; Suzuki et al. 1990; Suzuki 1994).

\section{Materials and methods}

\section{Specimens}

Eight individuals of $S$. caecutiens and five $S$. shinto were sampled from 12 localities of northern Eurasia (Table 1 and Fig. 1). Two individuals of Sorex shrew species (Sorex sp. of the $S$. caecutiens/shinto group) from Cheju Island, South Korea, were also examined.

\section{Southern hybridization and mapping of restriction sites}

Total genomic DNA was extracted from liver tissue preserved in $90 \%$ ethanol by the phenol/proteinase $\mathrm{K}$ / SDS method (Sambrook et al. 1989). The genomic DNA was digested with seven restriction enzymes, AatI (A), BglII (B), DraI (D), EcoRI (E), HindIII (H), PstI (P)

Table 1. Sorex shrew samples and their collection localities examined in this study.

\begin{tabular}{clcll}
\hline Species & Repetype & Locality No. & \multicolumn{1}{c}{ Locality } & Specimen Code \\
\hline S. shinto & & & & \\
& Shi-A & 1 & Mt. Kamegamori, Shikoku, Japan & SO97/5/25-1 \\
& Shi-B & 2 & Nagano Pref., Honshu, Japan & SO96misc-13 \\
& Shi-B & 3 & Ryotsu, Sado Is., Japan & HA5961 \\
& Shi-B & 3 & Ryotsu, Sado Is., Japan & HA5962 \\
& Shi-C & 4 & Mt. Hayachine, Honshu, Japan & SO97/8/5-1 \\
S. caecutiens & & & & \\
& Cae-A & 5 & Kaminokuni, Hokkaido, Japan & SO97/6/7-1 \\
& Cae-A & 6 & Sarobetsu moor, Hokkaido, Japan & SO94sc1 \\
& Cae-B & 7 & Trudovoe, Sakhalin, Russia & SO94sak5 \\
& Cae-C & 8 & Kedrovaya, Primorye, Russia & SO96/7/16-2 \\
& Cae-C & 9 & Mt. Gaya, South Korea & SO99misc-9 \\
& Cae-C & 10 & Mt. Odae, South Korea & SO99/10/17-1 \\
& Cae-C & 12 & Milkovo, Kamchatka, Russia & SO97misc-82 \\
& Cae-C & 13 & Pallasjärvi, Lapland, Finland & VH365 \\
& & & & \\
Sorex sp. & Sp-Cheju & 11 & Mt. Halla, Cheju Is., South Korea & SO99/10/12-1 \\
& Sp-Cheju & 11 & Mt. Halla, Cheju Is., South Korea & SO99/10/13-1 \\
\hline
\end{tabular}


and $P v u I I(V)$. After electrophoresis with $0.7 \%$ agarose gel for 17 hours at $30 \mathrm{~V}$, the digested DNA was immobilized on nylon membrane (Hybond-N, Amersham) and hybridized with digoxigenin-labeled (DIG DNA Labeling Kit and Detection Kit, Roche Diagnostics) 28S probe $(0.7 \mu \mathrm{g} / \mathrm{ml})$ from mouse (Suzuki et al. 1994). Detection of the probe on the membrane followed the supplier's protocol. Fragment lengths were determined by comparison with a size marker (DNA Molecular Weight
Marker II digoxigenin-labeled lambda HindIII). Restriction maps of the $28 \mathrm{~S}$ downstream spacer region were constructed by referring to the standard restriction map of the $18 \mathrm{~S}, 5.8 \mathrm{~S}$, and $28 \mathrm{~S}$ rRNA genes that are conservative among mammalian species (Suzuki et al. 1994; Iwasa et al. 2001).

\section{Phylogenetic analyses}

All restriction sites were numbered from 1 to 13 (Fig.
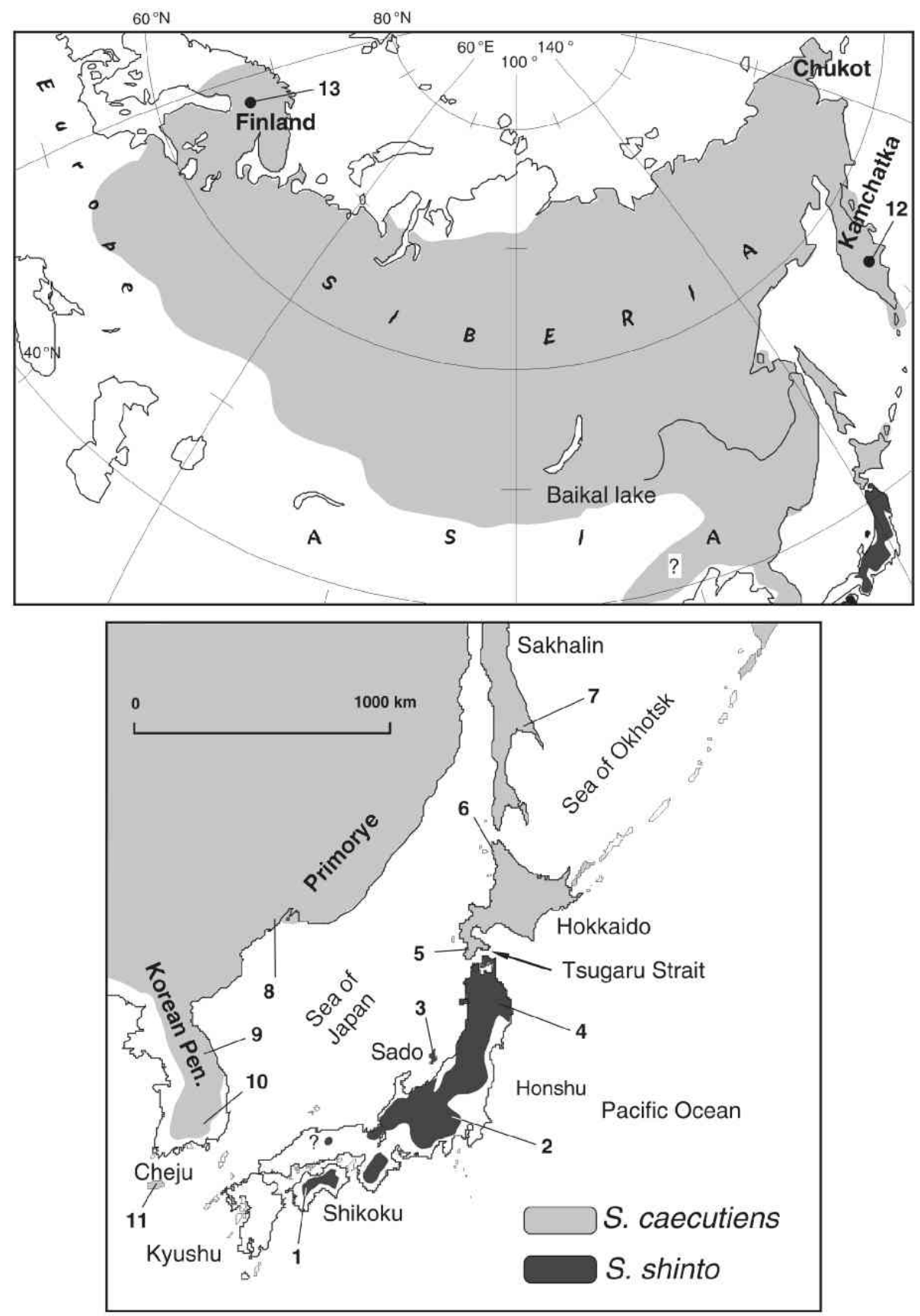

Fig. 1. Collection localities of shrew samples. Locality numbers correspond with those of Table 1 . 


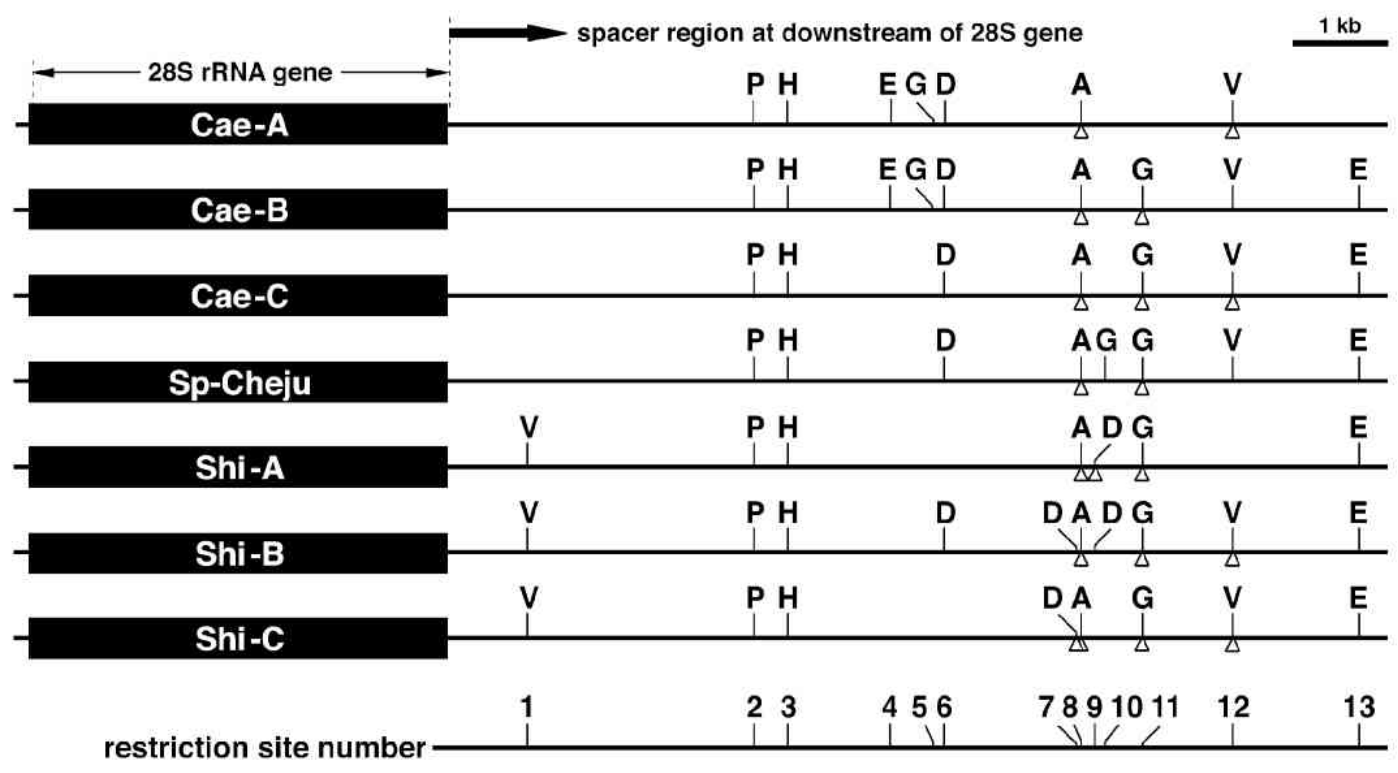

Fig. 2. Restriction maps of the major repeating unit types of the ribosomal RNA gene downstream of the $28 \mathrm{~S}$ coding region in the Sorex caecutiens/shinto group from various localities of Eurasia. Abbreviations of restriction enzymes: A, AatI; B, BglII; D, DraI; E, EcoRI; H, HindIII; P, PstI; V, PvuII. Among 15 individuals examined, some had identical repetitive types (repetypes). See Table 1 for individuals examined and their RFLP repetyes. Open triangles indicate polymorphic sites as size variation within a genome of an individual.

2) and converted into a $0 / 1$ data matrix, where a 0 indicates absence of the band and a 1 indicates presence. Phylogenetic analyses were conducted using the maximum parsimony method, applied using PAUP ver. $4.0 \mathrm{~b} 10$ (Swofford 2000) with the exhaustive search method and Dollo's criterion. The cost for gain of a restriction site was six times higher than for loss of a site because the restriction enzymes used all had a six base recognition sequence (Swofford and Olsen 1990). Nodal support was evaluated by 10,000 bootstrap replicates with $50 \%$ majority rule consensus. A parsimonious network was also constructed according to Bandelt (1994). This method indicates every change of state in a network. Thus, when the number of informative sites is small, this method is more straightforward than other methods of phylogeny reconstruction.

\section{Results}

\section{Restriction map}

Seven rDNA-RFLP repetitive types (repetypes) were recognized among 15 shrews examined (Fig. 2). The restriction patterns of $S$. shinto and $S$. caecutiens were distinguished by site 1 (Fig. 2). Four individuals of $S$. shinto showed three rDNA-RFLP repetitive type: Shi-A, Shi-B and Shi-C (Table 1, Fig. 2). In contrast, five individuals of $S$. caecutiens from several localities on the
Eurasian continent including the Korea Peninsula shared only one repetype (Cae-C; Table 1, Fig. 2). Two $S$. caecutiens individuals from Hokkaido had a single repetype (Cae-A; Table 1, Fig. 2), and sites 4 and 5 were not observed in Cae-C while sites 11 and 13 shown in Cae-C were absent in Cae-A (Fig. 2). The repetype from Sakhalin (Cae-B) had sites 4, 5, 11, and 13 (Fig. 2), demonstrating it contained characteristics of repetypes both from the continent (Cae-C) and Hokkaido (Cae-A). Two individuals from Cheju Island had a single repetype (Sp-Cheju), which showed a unique restriction site (site 10) but other sites were identical to the repetype (Cae-C) from the continent (Fig. 2).

\section{Cladogram and network}

One shortest tree (tree length $=16$ ) was obtained by the maximum parsimony method (Fig. 3). Sorex shinto and $S$. caecutiens were distinguished in the cladogram (Fig. 3) but the confidence of this division was statistically low (bootstrap values, $<50 \%$ ). The repetype from Sp-Cheju (Cheju Island) was included in the $S$. caecutiens clade and formed a subclade with Cae-C (Eurasian continent). The repetypes for Cae-A (Hokkaido) and Cae-B (Sakhalin) formed a second subclade within the S. caecutiens clade (Fig. 3).

In the phylogenetic network (Fig. 4A), S. caecutiens and $S$. shinto were distinguished by restriction site 1 , and 


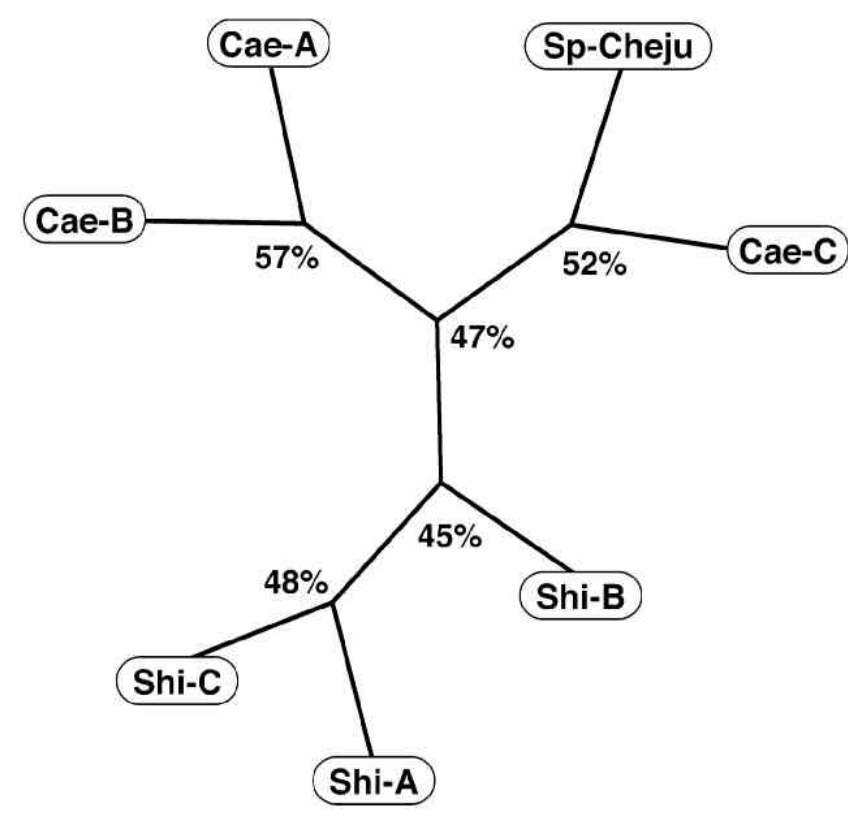

Fig. 3. Unrooted maximum parsimony tree based on nuclear rDNARFLP repetypes in the Sorex caecutiens/shinto group. Percent values are the bootstrap values after 10,000 replications. See Table 1 for acronyms of the rDNA-RFLP repetypes. the shrews from Cheju Island (Sp-Cheju) were most closely connected with $S$. caecutiens from the continent, as in the maximum parsimony tree. The phylogenetic network suggests that the repetype of Hokkaido (Cae-A) was derived from that of Sakhalin (Cae-B), which was in turn derived from that of the Eurasian continent (Cae-C). The divergence pattern within $S$. shinto was unclear (Fig. 4A).

In addition, it was observed that the mapping pattern of the restriction sites of Sakhalin (Cae-B) was the sum of the continental (Cae-C) and Hokkaido (Cae-A) types (Fig. 2); i.e., Cae-B was the intermingled type of Cae-C and Cae-A. Thus, allowing hybridization of the rDNARFLP pattern, an alternative network has been reconstructed (Fig. 4B).

\section{Discussion}

Previous phylogenetic studies based on mtDNA cyt- $b$ sequences (Ohdachi et al. 1997, 2001, 2003; Fumagalli et al. 1999) and allozymes (George 1988) demonstrated

\section{A. parsimonious network}

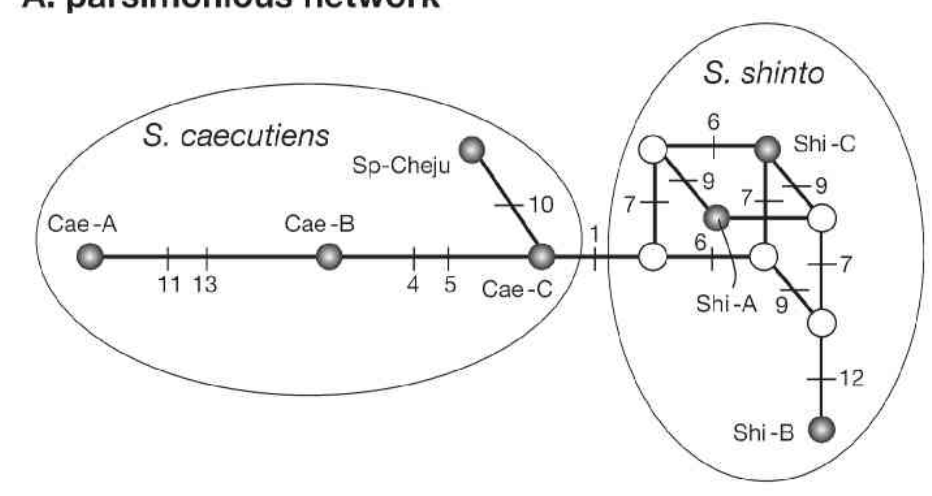

\section{B. network with hybridization}

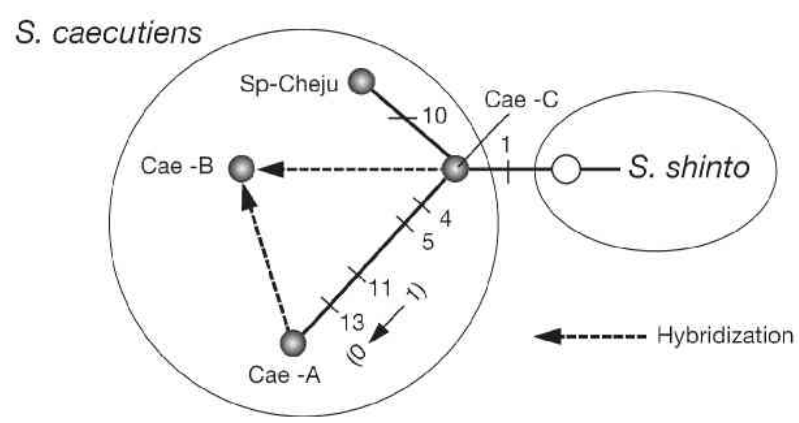

Fig. 4. Parsimonious network based on rDNA-RFLP repetypes (A) and a phylogenetic network allowing hybridization (B), based on rDNARFLP repetypes in the Sorex caecutiens/shinto group. Numbers near short bars denote those of the change of restriction sites. Site numbers correspond with those of Fig. 2. An open circle is a hypothetical taxonomic unit. Intraspecific relationships of $S$. shinto were omitted in the networks. See Table 1 for acronyms of the rDNA-RFLP repetypes. 


\section{A. hypothetical phylogeny (Tree 1)}

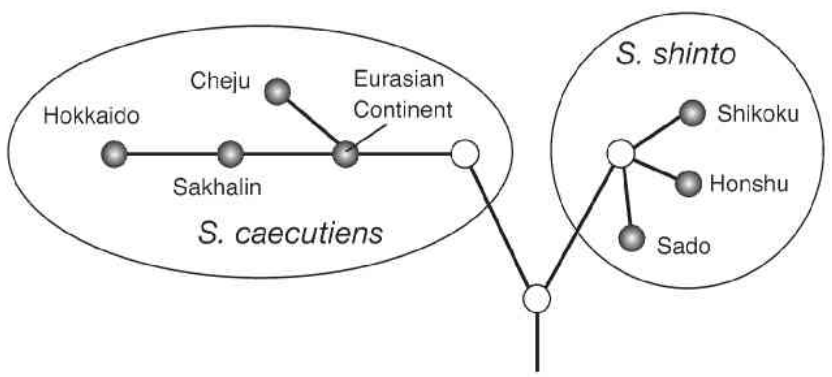

\section{B. hypothetical phylogeny (Tree 2)}

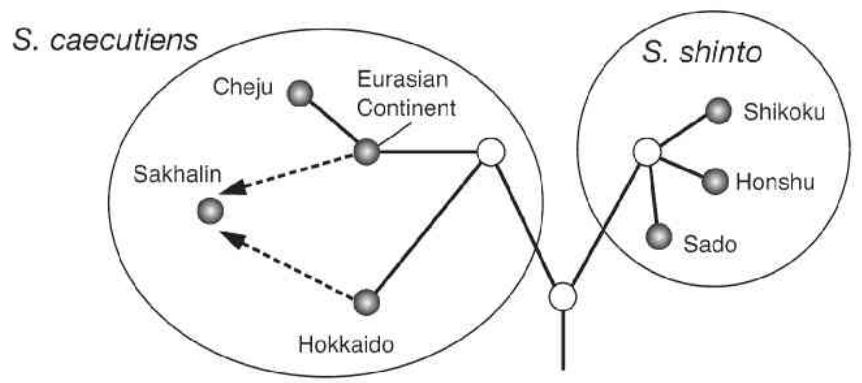

Fig. 5. Two hypothetical phylogenies of nuclear DNA in the Sorex caecutiens/shinto group, based on the rDNA-RFLP repetypes. Tree 1 (A) was inferred from the parsimonious network (Fig. 4A) and tree 2 (B) from the network allowing hybridization (Fig. 4B). Arrows with broken lines indicate hybridization.

that $S$. caecutiens and $S$. shinto should be treated as two separate species. In the present study, it was not statistically supported, although topology showed these two were separated (Fig. 3). However, the shrew from Cheju Island was most close to $S$. caecutiens in the Eurasian continent and it should be recognized as $S$. caecutiens (Fig. 3). In addition, although sampling locations from the Eurasian continent were greatly scattered, there was no variation in the rDNA-RFLP repetype within $S$. caecutiens over this range (Table 1, Fig. 2). The same tendency was observed in the genetic variation of mtDNA cyt- $b$ (Ohdachi et al. 2001, 2003; Ohdachi 2005). These findings from both nuclear DNA and mtDNA suggest that $S$. caecutiens has gone through a recent and rapid range expansion in the Eurasian continent. Patterns of genetic variation were largely different between Hokkaido and the continent both in rDNA-RFLP repetypes (Fig. 4) and mtDNA haplotypes (Ohdachi et al. 2001, 2003; Ohdachi 2005). Therefore, the range expansion of $S$. caecutiens in the continent must have occurred after Hokkaido and the continent were geologically separated after the last glacial period. It is estimated that Hokkaido and Sakhalin+Eurasian continent were separated ca. 12,000 years ago (Ohshima 1990). Thus, the great range expansion in the continent presumably began after

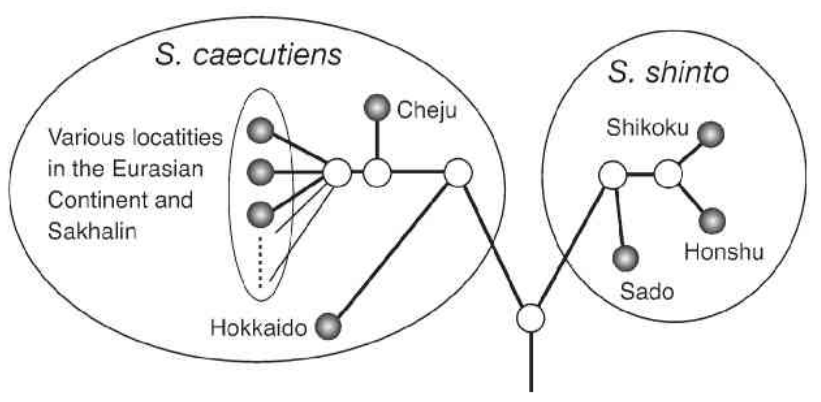

Fig. 6. Schematic tree of the mitochondrial DNA phylogeny in the Sorex caecutiens/shinto group, based on mtDNA cytochrome $b$ gene sequences (Ohdachi et al. 2003; Ohdachi in press). An open circle is a hypothetical taxonomic unit.

\section{2,000 years ago.}

The maximum parsimony tree (Fig. 3) and the phylogenetic network (Fig. 4A) were used to construct a hypothetical phylogeny of the nuclear rDNA (Tree 1, Fig. 5A). On the other hand, allowing hybridization between the rDNA-RFLPs, an alternative network was reconstructed (Fig. 4B), and from this phylogenetic network with hybridization, another hypothetical phylogeny was inferred (Tree 2, Fig. 5B).

We can not conclude which phylogeny (Fig. 5: trees 1 and 2) is more appropriate as an evolutionary process of 
the nuclear rDNA. A mtDNA phylogeny of the $S$. caecutiens/shinto group, was inferred (Fig. 6) based on Ohdachi et al. (2003) and Ohdachi (2005), where $S$. caecutiens was divided into Hokkaido and ContinentSakhalin-Cheju genealogies after $S$. caecutiens and $S$. shinto diverged. Hence, tree 2 is more congruent with the mtDNA phylogeny than tree 1 and for this reason seems the more appropriate phylogenetic tree (network) of the nuclear rDNA.

Acknowledgments: We wish to thank H. Abe, N. E. Dokuchaev, V. Haukisalmi, M. Yamagishi for offering shrew samples, G. Hinten for reviewing the manuscript, and K. Yoshizawa for supporting analysis of the maximum parsimony method. We also would like to express our gratitude to anonymous reviewers for critical comments.

\section{References}

Arheim, N., Krystal, M., Schmickel, R., Wilson, G., Ryder, O. and Zimmer, E. 1980. Molecular evidence for genetic exchanges among ribosomal genes on nonhomologous chromosomes in man and apes. Proceedings of the National Academy of Sciences of the United States of America 73: 7323-7327.

Bandelt, H. J. 1994. Phylogenetic networks. Verhandlungen des Naturwissenschaftlichen Vereins in Hamburg N. F. 34: 51-71.

Dokuchaev, N. E., Ohdachi, S. and Abe, H. 1999. Morphometric status of shrews of the Sorex caecutiens/shinto group in Japan. Mammal Study 24: 67-78.

Fumagalli, L., Taberlet, P., Stewart, D. T., Gielly, L. Hausser, J. and Vogel, P. 1999. Molecular phylogeny and evolution of Sorex shrews (Soricidae: Insectivora) inferred from mitochondrial DNA sequence data. Molecular Phylogenetics and Evolution 11: 222235 .

George, S. 1988. Systematics, historical biogeography, and evolution of the genus Sorex. Journal of Mammalogy 69: 443-461.

Iwasa, M. A., Ohdachi, S., Han, S.-H., Oh, H.-S., Abe, H. and Suzuki, H. 2001. Karyotype and RFLP of the nuclear rDNA of the Crocidura sp. on Cheju Island, South Korea. Mammalia 65: 451-459.

Iwasa, M. A. and Suzuki, H. 2002. Evolutionary networks of maternal and paternal gene lineages in Eothenomys voles endemic to Japan. Journal of Mammalogy 83: 852-865.
Mukai, T. 2001. Hybridization and introgression in the speciation process of fishes. Japanese Journal of Ichthyology 48: 1-18 (in Japanese with English summary).

Ohdachi, S. 2005. History of community organization of shrews in Hokkaido, inferred from DNA. In (R. Masuda and H. Abe, eds.) Natural History of Animal Biogeography. Hokkaido University Press, Sapporo (in Japanese) (in press).

Ohdachi, S., Masuda, R., Abe, H., Adachi, J., Dokuchaev, N. E., Haukisalmi, V. and Yoshida, M. C. 1997. Phylogeny of Eurasian soricine shrews (Insectivora, Mammalia) inferred from the mitochondrial cytochrome $b$ gene sequences. Zoological Science 14: 527-532.

Ohdachi, S., Dokuchaev, N. E., Hasegawa, M. and Masuda, R. 2001. Intraspecific phylogeny and geographic variation of six species of northeastern Asiatic Sorex shrews based on the mitochondrial cytochrome $b$ sequences. Molecular Ecology 10: 2199-2213.

Ohdachi, S. D., Abe, H. and Han, S.-H. 2003. Phylogenetical positions of Sorex sp. (Insectivora, Mammalia) from Cheju Island and $S$. caecutiens from the Korean Peninsula, inferred from mitochondrial cytochrome $b$ gene sequences. Zoological Science 20: 9195.

Ohshima, K. 1990. The history of straits around the Japanese Islands in the late-Quaternary. Daiyonki Kenkyu [The Quaternary Research] 29: 193-208 (in Japanese with English abstract).

Sambrook J., Fritsch, E. F. and Maniatis, T. 1989. Molecular Cloning: A Laboratory Manual, 2nd ed. Cold Spring Harbor Laboratory, New York.

Sota, T. and Vogler, A. P. 2001. Incongruence of mitochondrial and nuclear gene trees in the carabid beetles Ohomopterus. Systematic Biology 50: 39-59.

Suzuki, H. 1994. Genetic diversity of ribosomal DNA: phylogenetic analysis of small mammals. Honyurui Kagaku [Mammalian Science] 34: 67-79 (in Japanese with English abstract).

Suzuki, H., Tsuchiya, K., Sakaizumi, M., Wakana, S., Gotoh, O., Saitou, N., Moriwaki, K. and Sakurai, S. 1990. Differentiation of restriction sites in ribosomal DNA in the genus Apodemus. Biochemical Genetics 28: 137-149.

Suzuki, H., Kawamoto, Y., Takenaka, O., Munechika, I., Hori, H. and Sakurai, S. 1994. Phylogenetic relationships among Homo sapiens and related species based on restriction site variation in rDNA spacers. Biochemical Genetics 32: 257-269.

Swofford, D. L. 2000. PAUP*: phylogenetic analysis using parsimony (* and other methods). Version 4. Sinauer, Sunderland, Massachusetts.

Swofford, D. L. and Olsen, G. L. 1990. Phylogeny reconstruction. In (D. M. Hillis and C. Moritz, eds.) Molecular Systematics Pp. 411-501. Sinauer, Sunderland, Massachusetts.

Received 18 January 2005. Accepted 4 June 2005. 